\title{
ANALISIS LAMA WAKTU TUNGGU PELAYANAN PASIEN RAWAT JALAN DI BALAI KESEHATAN MATA MASYARAKAT PROPINSI SULAWESI UTARA
}

\author{
Neti M. Bustani \\ A. Joy Rattu \\ Josephine S. M. Saerang \\ ${ }^{1}$ Pasca Sarjana Universitas Sam Ratulangi Jurusan Ilmu Kesehatan Masyarakat \\ Bidang Minat Kajian Administrasi Rumah Sakit \\ Email: neti_bustani@yahoo.com
}

\begin{abstract}
Hospital has a mission to provide qualified health services and affordable by the community in order to improve public health; one of them was the short waiting time of patients. This study aimed to analyze the waiting time length (the arrival process, service, human resources) of outpatient services in the Public Eye Health Department of North Sulawesi. This study used a qualitative method by conducting interviews at 7 informants as the primary data; the secondary data were obtained from direct observation / observation in the Public Eye Health Department of North Sulawesi. The results showed that the patients' arrivals occurred before the registration counter was opened and most patients came with their families. During the service process there were some problems inter alia the patient did not bring his/her file/guarantee completely; the number of the registration booths were limited due to lack of staff; disrupted internet connection; as well as limited human resources who were experts in the field of refraction and medical records. Conclusion: The waiting time in the Public Eye Health Department of North Sulawesi was still quite long (> 60 minutes) due to the overload patients, lack of personnel at the registration booth, disrupted internet connection, delayed of distribution of medical record files, limited available rooms, and limited human resources that were expertised in the field of refraction and medical records
\end{abstract}

Keywords: waiting time, patients, the Public Eye Health Department of North Sulawesi

\begin{abstract}
Abstrak: Rumah Sakit mempunyai misi memberikan pelayanan kesehatan yang bermutu dan terjangkau oleh masyarakat dalam rangka meningkatkan derajat kesehatan masyarakat, salah satunya melalui waktu tunggu pasien yang cepat. Penelitian ini bertujuan untuk menganalisis lama waktu tunggu (proses kedatangan, pelayanan, sumber daya manusia) pelayanan pasien rawat jalan di Balai Kesehatan Mata Masyarakat (BKMM) Provinsi Sulawesi Utara (Sulut). Penelitian ini menggunakan metode kualitatif dengan melakukan wawancara pada 7 orang informan sebagai data primer, sedangkan data sekunder diperoleh dari pengamatan langsung/ observasi di BKMM Provinsi Sulut. Hasil penelitian mendapatkan kedatangan pasien di BKMM sudah terjadi sebelum loket pendaftaran dibuka dan kebanyakan pasien datang dengan diantar oleh keluarganya. Selama proses pelayanan ada beberapa kendala yang terjadi antara lain pasien tidak membawa berkas/jaminan yang lengkap, jumlah loket pendaftaran yang terbatas karena kurangnya petugas, ruangan yang kurang memadai, adanya gangguan koneksi internet, serta keterbatasan sumber daya manusia yang ahli dibidang refraksi dan rekam medik. Simpulan: Waktu tunggu di BKMM Provinisi Sulut masih tergolong lama (> 60 menit) yang disebabkan
\end{abstract}


jumlah pasien yang banyak, kurangnya petugas di loket pendaftaran dan BPJS, gangguan koneksi internet, pendistribusian berkas rekam medik yang sering terlambat, keterbatasan ruangan yang ada, dan keterbatasan SDM yang mempunyai keahlian di bidang refraksi dan rekam medik

Kata kunci: waktu tunggu, pasien, BKMM

Menurut World Health Organization (WHO), Rumah Sakit (RS) adalah bagian integral dari suatu organisasi sosial dan kesehatan dengan fungsi menyediakan pelayanan paripurna (komprehensif), penyembuhan penyakit (kuratif), dan pencegahan penyakit (preventif) kepada masyarakat. ${ }^{1}$ Berdasarkan Undang-Undang No. 44 Tahun 2009, RS adalah institusi pelayanan kesehatan yang menyelenggarakan pelayanan kesehatan perorangan secara paripurna yang menyediakan pelayanan rawat inap, rawat jalan, dan gawat darurat. ${ }^{2}$ Rumah Sakit Umum (RSU) mempunyai misi memberikan pelayanan kesehatan yang bermutu dan terjangkau oleh masyarakat dalam rangka meningkatkan derajat kesehatan masyarakat. Salah satu dimensi mutu pelayanan kesehatan adalah akses terhadap pelayanan yang ditandai dengan waktu tunggu pasien. ${ }^{3}$

Waktu tunggu adalah waktu yang digunakan pasien untuk mendapatkan pelayanan kesehatan mulai tempat pendaftaran sampai masuk ke ruang pemeriksaan dokter. Waktu tunggu pasien merupakan salah satu komponen yang potensial menyebabkan ketidakpuasan. Lama waktu tunggu pasien mencerminkan bagaimana RS mengelola komponen pelayanan yang disesuaikan dengan situasi dan harapan pasien. ${ }^{4}$

Kategori jarak antara waktu tunggu dan waktu periksa yang diperkirakan bisa memuaskan atau kurang memuaskan pasien antara lain yaitu saat pasien datang mulai dari mendaftar ke loket, antri dan menunggu panggilan ke poli umum untuk dianamnesis dan diperiksa oleh dokter, perawat atau bidan lebih dari 90 menit (kategori lama), 30 - 60 menit (kategori sedang) dan $\leq 30$ menit (kategori cepat). ${ }^{4}$ Waktu tunggu di Indonesia ditetapkan oleh Kementrian Kesehatan (Kemenkes) melalui standar pelayanan minimal. Setiap RS harus mengikuti standar pelayanan minimal tentang waktu tunggu ini. Standar pelayanan minimal di rawat jalan berdasar Kemenkes Nomor 129/Menkes/SK/II/2008 ialah kurang atau sama dengan 60 menit. $^{5}$

Balai Kesehatan Mata Masyarakat (BKMM) Provinsi Sulawesi Utara (Sulut) merupakan salah satu fasilitas kesehatan yang dikelola oleh pemerintah Provinsi Sulut yang khusus melayani masalah kesehatan mata dan merupakan pusat pelayanan kesehatan mata masyarakat terbaik di Indonesia Timur bagian Utara, sehingga dituntut untuk memberikan pelayanan yang sebaik-baiknya kepada masyarakat. Pelayanan yang baik akan memberikan kepuasan kepada masyarakat sebagai penerima jasa pelayanan. ${ }^{6}$ Berdasarkan data tahun 2012 terdapat 23.894 pasien rawat jalan di BKMM Provinsi Sulut dan meningkat menjadi 42.406 pasien pada tahun 2014, yang berarti meningkatnya kepadatan jumlah antrian pendaftaran di RS dan hal ini akan berdampak pada waktu tunggu pasien dapat menjadi semakin lama.

Berdasarkan hasil wawancara langsung awal bulan Februari 2015 di BKMM Provinsi Sulut pada 5 orang pasien menunjukkan waktu tunggu pasien antara 100-200 menit untuk mendapatkan pelayanan medis, yaitu mulai dari kedatangan pasien untuk mengambil nomor antrian sampai mendapatkan pemeriksaan oleh dokter. Tidak jarang pasien langsung menyampaikan keluhannya karena menunggu terlalu lama untuk 
mendapatkan pemeriksaan oleh dokter, dimana waktu bertemu untuk diperiksa dokter dirasakan terlalu singkat jika disbandingkan dengan waktu yang dihabiskan untuk menunggu panggilan diperiksa oleh dokter.

Berdasarkan latar belakang diatas dan sampai saat ini belum ada laporan tertulis tentang lama waktu tunggu pelayanan di BKMM Provinsi Sulut yang dilaporkan, maka penulis melakukan penelitian kualitatif tentang lama waktu tunggu pelayanan pasien rawat jalan di BKMM Provinsi Sulut. Penelitian ini bertujuan untuk menganalisis lama waktu tunggu (proses kedatangan, pelayanan, sumber daya manusia) pelayanan pasien rawat jalan di BKMM Provinsi Sulut.

\section{METODE PENELITIAN}

Penelitian ini menggunakan metode kualitatif melalui wawancara pada 7 orang informan (data primer) dengan mengguna- kan panduan wawancara. Data sekunder diperoleh dari pengamatan langsung di BKMM yang dilakukan oleh peneliti sendiri dengan mengisi lembar observasi. Penelitian dilakukan pada bulan April sampai dengan bulan November 2015, di BKMM Provinsi Sulut.

Analisis data pada penelitian ini menggunakan content analysis dengan langkah-langkah sebagai berikut: pengumpulan data, reduksi data, penyajian data, pemeriksaan keabsahan data dan analisis komponen hasil penelitian. ${ }^{7}$ Untuk mendapatkan keabsahan data, dilakukan dengan teknik triangulasi yaitu triangulasi sumber dan triangulasi metode.

\section{HASIL PENELITIAN}

Informan pada penelitian ini dapat dilihat pada tabel karakteristik informan (Tabel 1)

Tabel 1. Karakteristik Informan

\begin{tabular}{|c|c|c|c|c|c|c|}
\hline Informan & $\begin{array}{l}\text { Umur } \\
\text { (thn) }\end{array}$ & $\begin{array}{c}\text { Jenis } \\
\text { Kelamin }\end{array}$ & Jabatan & $\begin{array}{c}\text { Pengalaman } \\
\text { kerja (Thn) }\end{array}$ & $\begin{array}{c}\text { Pendidikan } \\
\text { terakhir }\end{array}$ & Singkatan \\
\hline 1 & 48 & $\mathrm{P}$ & Kepala BKMM & 22 & $\begin{array}{l}\text { Spesialis } \\
\text { Mata } 2\end{array}$ & $\begin{array}{c}\text { Kep. } \\
\text { BKMM }\end{array}$ \\
\hline 2 & 44 & $\mathrm{P}$ & $\begin{array}{c}\text { Kepala Seksi } \\
\text { Pelayanan Medik }\end{array}$ & 21 & S1 & KSPM \\
\hline 3 & 45 & $\mathrm{P}$ & $\begin{array}{l}\text { Kepala Rekam } \\
\text { Medis }\end{array}$ & 20 & SMA & KRM \\
\hline 4 & 39 & $\mathrm{P}$ & $\begin{array}{c}\text { Penanggung Jawab } \\
\text { Rawat Jalan }\end{array}$ & 20 & S2 & PJRJ \\
\hline 5 & 48 & $\mathrm{P}$ & Dokter Mata & 21 & $\begin{array}{l}\text { Spesialis } \\
\text { Mata } 2\end{array}$ & SpM 1 \\
\hline 6 & 40 & $\mathrm{P}$ & Dokter Mata & 13 & $\begin{array}{l}\text { Spesialis } \\
\text { mata } 1\end{array}$ & SpM 2 \\
\hline 7 & 33 & $\mathrm{P}$ & $\begin{array}{l}\text { Petugas loket } \\
\text { pendaftaran }\end{array}$ & 3 & SMA & PLP \\
\hline
\end{tabular}




\section{Proses Kedatangan}

Pertanyaan 1: Bagaimana proses kedatangan (waktu dan cara datang) pasien rawat jalan di BKMM Provinsi Sulut?

Jawab (PLP): 'pasien-pasien di BKMM ini sudah datang dari loket belum buka, ada yang masih subuh so ada di halaman BKMM, kebanyakan datang diantar keluarga”.

Jawab (KRM): "pasien selalu datang sebelum loket pendaftaran dibuka sehingga saat loket buka pasien so banyak sekali karena rata-rata pasien mata yang datang ke sini orang tua, jadi selalu ada keluarga yang antar."

Jawab (PJRJ): "rata-rata pasien datang sebelum loket buka, apalagi pasien yang dari luar Manado ada yang sudah datang dari jam 5 pagi so di BKMM, padahal loket pendaftaran nanti buka jam 8 pagi."

"ada yang datang sendiri, tapi kalau yang sudah tua biasanya ada yang antar, yang mau beperiksa mata satu orang mar yang antar 3-5 orang."

Rata-rata informan mengatakan kebanyakan pasien datang sebelum loket pendaftaran dibuka dan datang dengan diantar oleh keluarganya.

Pertanyaan 2: Bagaimana cara pengambilan nomor antrian?

Jawab (PLP): “kalau baru mau mulai ambil nomor antrian, tu pasien (kalau masih muda) atau keluarga pasien (pasien tua) so baku ruju for mau dapa tu nomor antrian, sehingga so nda dapa tau mana tu pasien yang datang pertama”.

Jawab (PJRJ): "saat loket pengambilan nomor antrian buka, pasien-pasien sudah rebutan untuk dapat nomor antrian sampai berdesak-desakan, jadi kita sudah tidak tahu mana pasien yang datang awal mana yang akhir, tidak jarang pasien-pasien saling marah karena yang datang lebih dulu tapi dapat nomor antrian yang lebih belakang. Hal ini biasanya terjadi saat awal loket buka saja karena saat loket buka sudah banyak pasien yang menunggu untuk mengambil nomor antrian, setelah jam 9 keatas pengambilan nomor antrian berjalan lebih tertib".

Jawab (KSPM): "pengambilan nomor antrian dilakukan pada loket khusus pengambilan nomor antrian, sehingga di loket ini setiap pagi banyak terjadi keramaian karena pasien sudah tidak sabar untuk mengambil nomor antrian. Saat loket buka, pasien maupun keluarga pasien sudah langsung berebutan untuk mendapatkan nomor antrian. Hal ini terjadi karena keterbatasan ruang di BKMM Provinsi Sulut sehingga belum memungkinkan kami untuk membuat jalur antrian buat pasien”.

Rata-rata informan mengatakan bahwa pasien atau keluarga pasien selalu berebutan untuk mendapatkan nomor antrian.

\section{Waktu Proses}

Pertanyaan 1: Apa kendala dalam pelaksanaan pelayanan pasien rawat jalan di BKMM Provinsi Sulut mengenai waktu proses/waktu pelayanan dimulai saat dipanggil ke loket pendaftaran sampai diperiksa oleh dokter?

Jawab (PLP): "pasien dipanggil sesuai dengan nomor antrian, kalau pasien lama kasi tunjuk surat pengenal pasien dan kebanyakan pasien adalah BPJS jadi harus kasi masuk semua berkas yang menjadi persyaratan. Seringkali pasien nda foto copy tu berkas atau tu berkas sudah foto copy tapi cuma 1 lembar, sehingga pas ditanya berkasberkasnya tidak lengkap sehingga harus pigi foto copy dulu baru balik lagi ke loket pendaftaran. Kalau pasien yang lengkap semua berkasnya langsung 
disuruh tunggu panggilan di ruang pemeriksaan refraksi, sementara dibuatkan surat eligibilitas peserta (SEP)nya dan petugas mencari berkas rekam mediknya."

Jawab (KRM): "kalau loket pendaftaran baru buka biasanya baru 2 sampai 3 orang yang melayani di pendaftaran karena ada yang masi pigi smokol dulu sebelum bertugas. Kalau berjalan normal biasanya satu kali jalan ada 5 petugas. Belum lagi kalau ada gangguan internet sehingga sudah banyak tumpukan berkas yang harus dibuatkan SEPnya tapi belum bisa karena internet ada gangguan. Kalau semua berkas sudah lengkap baru berkas rekam medis diantar ke ruang pemeriksaan refraksi dulu baru setelah diperiksa disitu baru masuk ke ruang dokter".

Jawab (PJRJ): "sebelum pasien mendapatkan pemeriksaan dokter memang cukup banyak waktu yang dihabiskan pasien. Ini karena ada prosedur administrasi dan pemeriksaan yang harus di lewati pasien. Untuk administrasi karena rata-rata pasien adalah BPJS maka harus lengkap semua persyaratan dan kadang-kadang ada pasien yang tidak lengkap berkasnya sehingga harus melengkapi dulu baru dilayani kembali, belum lagi kalau terjadi gangguan internet sehingga semakin menumpuk berkas yang harus diselesaikan untuk pembuatan SEP pasien sehingga pelayanan selanjutnya belum bisa berjalan. Juga ada kesalahan dalam penyimpanan kartu sehingga saat dicari kartu tidak ada dan harus dicari terutama untuk pasien-pasien yang akan dilakukan pemeriksaan atau tindakan khusus, dan kalau kartu tidak ketemu maka dokter harus memulai pemeriksaan dari awal lagi dan ini sangat memakan waktu pelayanan. Untuk pemeriksaan masih terpusat di satu tempat artinya belum per sub unit sehingga dalam pelayanan semua pasien (gangguan refraksi, infeksi, gangguan retina, glaucoma) masuk ke satu ruangan yang sama”.

Rata-rata informan mengatakan bahwa pasien seringkali tidak membawa berkas persyaratan BPJS dengan lengkap, tidak membawa kartu pengenal pasien, gangguan internet dan ada petugas yang tidak tepat waktu dalam melaksanakan tugasnya.

\section{Ketersediaan Sumber Daya}

Pertanyaan 1: Bagaimana SDM yang terlibat dalam pelayanan pasien rawat jalan di BKMM Provinsi Sulut mulai dari loket pendaftaran, pemeriksaan refraksi, pemerisaan penunjang, sampai dokter dalam hal ini mengenai jumlah, pendidikan dan masa kerja. Apakah hal tersebut memengaruhi waktu tunggu pasien?

Jawab (Kep. BKMM): "SDM sangat memengaruhi pelayanan. Secara jumlah cukup, hanya saja ada beberapa bagian pelayanan seperti refraksi yang seharusnya dilakukan oleh refraksionis, di BKMM ini dilakukan oleh perawat yang dilatih untuk hal tersebut untuk membantu refraksionis melaksanakan tugasnya. Saat ini BKMM hanya memiliki 1 orang refraksionis. Untuk pendidikan tentu saja memengaruhi pelayanan karena orang dengan latar belakang pendidikan tertentu akan lebih baik dalam melakukan pekerjaan yang sesuai dengan latar belakang pendidikannya. Masa kerja juga sangat memengaruhi keterampilan seseorang dalam melakukan pekerjaan”.

Jawab (KSPM): “Berdasarkan analisis beban kerja yang pernah dilakukan, jumlah pegawai di BKMM masih kurang dibandingkan dengan jumlah pasien yang harus dilayani setiap hari yang rata-rata 150-200 orang. Untuk pendidikan, hampir semua tenaga 
spesifik (yang terlibat langsung dalam pelayanan seperti refraksi, pemeriksaan penunjang, pemeriksaan diagnostik dan dokter) sudah pernah diberikan pelatihan ditempat yang berkompeten khusus mata seperti Rumah Sakit Cicendo maupun RSCM.

Jawab (PJRJ): "SDM dengan latar pendidikan rekam medik belum ada, sehingga pasien dengan kunjungan lama perlu dilakukan pencarian kartu pasien dan kadang-kadang pencarian kartu agak lama karena kesalahan penyimpanan kembali berkas rekam medik. Jumlah petugas khususnya dibagian pendaftaran masih kurang karena idealnya 7 loket pendaftaran sekaligus jalan tapi pada prakteknya hanya 3 sampai 5 saja. Petugas di bagian verifikasi data juga masih kurang”.

Jawab (SpM1): "Saya rasa secara umum jumlah sudah cukup, hanya saja pada bagian tertentu seperti di bagian pendaftaran petugasnya kurang. Begitu juga dengan petugas BPJS, dengan pasien yang banyak dilayani setiap hari kalau hanya 2 sampai 3 petugas di BPJS itu sangat kurang. Kalau untuk jumlah perawat dan dokter mata sudah cukup saya rasa. Tapi kedepan harus ada penambahan dokter sub spesialis mata. Pendidikan memang memengaruhi juga, tapi setahu saya rerata tingkat pendidikan pegawai di BKMM ini SLTA ke atas untuk yang ditugaskan di bagian administrasi sedangkan untuk perawat dan dokter sudah sesuai dengan kompetensinya. Untuk masa kerja pasti memengaruhi secara tidak langsung”.

Rata-rata informan mengatakan secara umum jumlah pegawai sudah cukup hanya saja ada bagian-bagian tertentu yang jumlah pegawainya kurang jika dibandingkan dengan jumlah kunjungan pasien yang ratarata 150 sampai 200 orang perhari.
Pertanyaan 2: Apakah sarana dan prasarana yang ada sudah mendukung cepatnya pelayanan pasien rawat jalan di BKMM Provinsi Sulut?

Jawab (Kep. BKMM): "Sarana untuk pemerisaan pasien sudah sangat mendukung, dimana tersedia alat-alat untuk pemeriksaan, penunjang diagnosis dan operasi yang bisa dikatakan terbaik yang ada di Manado. Hanya saja sarana untuk kegiatan administrasi dan rekam medik kita masih menggunakan sistem manual sehingga ada beberapa rekam medik yang tercecer atau salah dalam penyimpanannya dan hal ini mengakibatkan keterlambatan pelayanan pasien. Untuk prasarana memang sangat kurang memadai, dimana dengan bangunan yang seperti ini dengan keterbatasan ruangan dan harus melayani pasien yang banyak setiap harinya. Kita hanya bisa memanfaatkan semaksimal mungkin ruangan yang ada untuk melakukan pelayanan kepada pasien. Sebagai contoh jika prasarana kita memungkinkan maka loket pendaftaran dapat dibeda-bedakan untuk pasien lama atau baru, umum atau BPJS, ruangan pemeriksaan bisa diperbanyak dan poli dokter setiap harinya biasa berjalan 5 dokter sekalian poli, tapi keadaan sekarang tidak memungkinkan untuk melakukan hal tersebut".

Jawab (KSPM): "Peralatan yang ada sudah sangat mendukung hanya saja banguan yang tidak menunjang pelayanan secara maksimal. Seperti yang bisa kita lihat karena jumlah pasien yang sangat membludak sehingga ruang tunggu di dalam ruangan sudah tidak mampu lagi menampung pasien sehingga pasien harus menunggu di luar bangunan dengan menggunakan tenda. Penempatan alat-alat juga tidak maksimal dimana seharusnya satu ruangan diisi 2 sampai 3 macam alat pemeriksaan tapi karena tidak cukup tempat maka dalam 
satu ruangan bisa ada sampai 5 alat sehingga hal itu juga memengaruhi lamanya pelayanan yang akan diberikan karena pasien harus antri untuk masuk ke dalam ruangan. Ruang pemeriksaan dokter juga terbatas sehingga maksimal sehari hanya bisa jalan 3 dokter saja untuk melayani pasien yang sebegitu banyak".

Jawab (SpM2): “Untuk sarana dalam hal alat untuk pemeriksaan pasien sudah sangat baik. Tapi untuk jaringan internet sering terjadi gangguan dan jumlah komputer untuk pembuatan SEP masih kurang sehingga pelayanan pasienpun terhambat. Untuk bangunan yang ada saat ini memang dirasa kurang memadai untuk menampung pasien yang banyak setiap harinya. Pasien-pasien yang sudah tidak mendapat tempat tunggu di dalam ruangan harus menunggu di luar sehingga sering kali pasien tersebut tidak mendengar kalau namanya dipanggil”.

Rata-rata informan menyatakan kalau sarana dalam hal ini adalah alat pemeriksaan pasien sudah sangat menunjang hanya saja prasarana dalam hal ini gedung yang kurang mendukung pelayanan pasien secara maksimal.

Pertanyaan 3: Faktor-faktor apa saja yang menjadi penyebab lama waktu tunggu pelayanan pasien rawat jalan di BKMM Provinsi Sulut?

Jawab (Kep. BKMM): “Faktor yang paling utama menyebabkan lama waktu tunggu pasien karena sistem yang digunakan masih manual dan keterbatasan ruangan”.

Jawab (KSPM): “Kalau dilihat dari sisi pasien karena banyaknya jumlah kunjungan pasien tiap harinya dan juga pasien lama yang lupa membawa kartu pengenal pasien ataupun berkas yang tidak lengkap. Kalau dari sisi kita sebagai pemberi layanan kebanyakan karena faktor teknis seperti gangguan internet, kurangnya petugas di loket pendaftaran dan keterbatasan ruangan".

Jawab (KRM): "kurangnya petugas di loket pendaftaran dan adanya petugas yang tidak tepat waktu dalam melaksanakan tugasnya. Adanya gangguan internet dan jumlah pasien yang banyak".

Jawab (PJRJ): "Menurut saya karena tenaga masih kurang terutama yang di bagian administrasi dan rekam medik sementara pasien yang harus dilayani sangat banyak, juga karena sering kali terjadi gangguan koneksi internet dan ruangan yang belum memadai.

Jawab (SpM1):"Saya rasa yang menjadi faktor utamanya adalah dibagian administrasi karena kalau berkas pasien sudah masuk ke ruang pemeriksaan biasanya tidak lama setelah itu pasien sudah diperiksa oleh dokter".

Rata-rata informan mengatakan yang menjadi faktor penyebab lama waktu tunggu adalah ruangan yang belum memadai, jumlah pasien yang banyak, jumlah petugas di loket pendaftaran kurang dan seringnya terjadi gangguan koneksi internet.

\section{Hasil Observasi}

Berdasarkan hasil observasi langsung di lapangan untuk lama waktu pelayanan pasien rawat jalan di BKMM Provinsi Sulut didapatkan hasil waktu tunggu yang lama. Hasil observasi langsung waktu tunggu pasien di BKMM Provinsi Sulut dapat dilihat pada Tabel 2. 
Tabel 2. Hasil observasi langsung waktu tunggu pasien di BKMM Provinsi Sulut

\begin{tabular}{|c|c|c|c|c|c|c|c|c|c|c|c|c|c|c|c|c|}
\hline \multirow[b]{2}{*}{ no } & \multirow{2}{*}{$\begin{array}{l}\text { nomor } \\
\text { antrian }\end{array}$} & \multirow{2}{*}{$\begin{array}{c}\text { loket } \\
\text { nomor }\end{array}$} & \multirow{2}{*}{$\begin{array}{c}\text { Loket } \\
\text { pendaftaran }\end{array}$} & \multicolumn{2}{|r|}{ BPJS } & \multicolumn{2}{|c|}{ rekam medik } & \multicolumn{2}{|c|}{ refraksi } & \multicolumn{2}{|c|}{ poli (dokter) } & \multicolumn{2}{|c|}{ BPJS } & \multicolumn{2}{|c|}{ apotik } & \multirow{2}{*}{$\begin{array}{c}\text { waktu } \\
\text { tunggu } \\
\text { menit }\end{array}$} \\
\hline & & & & masuk & SEP & masuk & selesai & masuk & periksa & masuk & periksa & masuk & selesai & masuk & obat & \\
\hline 1 & 1 & 08,00 & 08,10 & 08,15 & $08,20-08,23$ & 08,50 & 08,55 & 09,10 & 09,12 & 09,15 & 09,30 & 09,40 & 09,50 & 09,50 & 09,55 & 115 \\
\hline 2 & 2 & 08,00 & 08,10 & 08,13 & $08,15-08,20$ & 08,50 & 08,53 & 09,10 & 09,12 & 09,17 & 09,30 & 09,42 & 09,50 & 09,50 & 09,55 & 115 \\
\hline 3 & 3 & 08,00 & 08,10 & 08,13 & $08,15-08,20$ & 08,50 & 08,57 & 09,10 & 09,12 & 09,15 & 09,35 & 09,45 & 09,51 & 09,51 & 09,55 & 115 \\
\hline 4 & 4 & 08,00 & 08,14 & 08,20 & $08,22-08,27$ & 08,50 & 09,00 & 09,10 & 09,16 & 09,20 & 09,35 & 09,44 & 09,51 & 09,55 & 10,00 & 120 \\
\hline 5 & 5 & 08,00 & 08,14 & 08,20 & $08,23-08,28$ & 08,50 & 09,00 & 09,10 & 09,16 & 09,20 & 09,40 & 10,00 & 10,00 & 10,00 & 10,03 & 123 \\
\hline 6 & 6 & 08,01 & 08,20 & 08,25 & $08,30-08,35$ & 08,50 & 09,02 & 09,10 & 09,16 & 09,20 & 09,40 & 09,45 & 09,51 & 09,52 & 09,57 & 116 \\
\hline 7 & 7 & 08,01 & 08,21 & 08,25 & $08,30-08,35$ & 08,50 & 09,06 & 09,10 & 09,20 & 09,25 & 09,48 & 09,50 & 09,52 & 09,52 & 09,58 & 117 \\
\hline 8 & 8 & 08,01 & 08,25 & 08,30 & $08,37-08,42$ & 08,50 & 09,05 & 09,10 & 09,22 & 09,25 & 09,50 & 09,53 & 09,55 & 09,57 & 10,00 & 119 \\
\hline 9 & 9 & 08,01 & 08,26 & 08,33 & $08,38-08,45$ & 08,50 & 09,05 & 09,10 & 09,20 & 09,30 & 09,50 & 09,55 & 09,55 & 09,57 & 10,00 & 119 \\
\hline 10 & 10 & 08,01 & 08,32 & 08,35 & $08,45-08,50$ & 08,50 & 09,06 & 09,10 & 09,25 & 09,30 & 10,00 & 10,10 & 10,10 & 10,10 & 10,15 & 134 \\
\hline 11 & 48 & 08,09 & 09,10 & 09,15 & $10,53-10,57$ & 11,05 & 11,08 & 11,18 & 11,30 & 11,26 & 11,40 & 11,50 & 12,00 & 12,00 & 12,05 & 236 \\
\hline 12 & 49 & 08,09 & 09,12 & 09,18 & $10,54-10,57$ & 11,05 & 11,15 & 11,18 & 11,32 & 11,35 & 11,43 & 11,48 & 12,00 & 12,00 & 12,03 & 234 \\
\hline 13 & 50 & 08,09 & 09,12 & 09,15 & $10,54-11,00$ & 11,05 & 11,10 & 11,18 & 11,32 & 11,37 & 11,48 & 11,55 & 12,00 & 12,00 & 12,03 & 234 \\
\hline 14 & 51 & 08,10 & 09,20 & 09,23 & $10,57-11,00$ & 11,05 & 11,09 & 11,18 & 11,33 & 11,40 & 11,51 & 11,55 & 12.01 & 12.02 & 12,05 & 235 \\
\hline 15 & 52 & 08,10 & 09,21 & 09,25 & $10,57-11,02$ & 11,05 & 11,10 & 11,18 & 11,33 & 11,38 & 11,55 & 12,00 & 12,02 & 12.02 & 12,05 & 235 \\
\hline
\end{tabular}




\section{BAHASAN}

\section{Proses Kedatangan}

Hasil wawancara mendalam tentang lama waktu tunggu pasien pada proses kedatangan menunjukkan bahwa kedatangan pasien sudah terjadi sebelum loket pendaftaran di buka, sehingga saat loket pendaftaran di buka sudah banyak pasien yang mengantri untuk mengambil nomor antrian. Apalagi kalau pasien yang berasal dari luar kota Manado biasanya mereka sudah tiba di BKMM Provinsi Sulut sejak masih subuh, padahal loket pendaftaran baru buka pada pukul 08.00 WITA.

Berdasarkan hasil observasi lapangan langsung yang dilakukan didapatkan bahwa antrian di BKMM ini sudah terjadi sebelum jam pelayanan dan ini dapat dilihat berdasarkan pengamatan yang dilakukan bahwa halaman BKMM sudah dipadati oleh pasien dan keluarga sebelum jam pelayanan dimulai.

Kebanyakan pasien datang dengan diantar oleh keluarganya, bahkan ada yang diantar oleh tiga sampai lima orang, dimana hal ini menambah kepadatan di ruang tunggu pasien yang tidak terlalu besar. Rata-rata jumlah kunjungan adalah 150 sampai 200 orang per hari sehingga ada pasien yang harus menunggu di luar gedung yang hanya beratapkan tenda dikarenakan ruang tunggu yang ada tidak dapat menampung seluruh pasien beserta keluarganya.

Berdasarkan teori dikatakan apabila pada suatu sistem pelayanan dengan kapasitas C akan dimasuki oleh input sebesar i. Jika tingkat pelayanan $\mathrm{S}$ dalam sistem untuk merespon tingkat input i lebih lambat dari laju input $i$, maka akan terjadi antrian sebesar Q. Dapat dikatakan bahwa terjadinya antrian yang menyebabkan lama waktu tunggu pada dasarnya ialah representasi dari perbandingan antara tingkat input i dengan tingkat pelayanan dari sistem $S$ dengan nilai $>1$. Sebaliknya apabila nilai perbandingan tersebut $<1$ maka antrian yang menyebabkan waktu tunggu tidak akan terjadi bahkan sistem mengalami idle atau waktu jeda. ${ }^{8}$

Hal senada juga diutarakan oleh Khasanah et al. ${ }^{9}$ dalam tugas akhir yang berjudul analisis sistem pelayanan pasien pada poli mata RSU Kabupaten Gresik dikatakan bahwa antrian yang panjang akan menyebabkan waktu tunggu yang lama pula. Hal ini akan meyebabkan kerugian, ketidakpastian dan kejenuhan. Antrian sering terjadi karena banyaknya konsumen atau pelanggan sehingga melebihi kapasitas pelayanan atau kemampuan melayani yang ada.

Dalam penelitian Esti ${ }^{4}$ tentang pengaruh waktu tunggu dan waktu sentuh pasien terhadap tingkat kepuasan pasien poli umum di Puskesmas Sukorame Kota Kediri didapatkan bahwa dalam satu hari ada sekitar 124 sampai 175 orang pasien yang berkunjung ke Puskesmas Sukorame, jadi sudah tentu membutuhkan antrian yang menyebabkan lama waktu tunggu pasien menjadi lama karena pasien yang berkunjung juga sangat banyak.

Pengambilan nomor antrian dimulai pada pukul 08.00 WITA pada loket khusus untuk pengambilan nomor antrian dengan memakai mesin. Pada saat loket dibuka, pasien dan keluarga pasien sudah berebutan untuk mendapatkan nomor antrian karena belum ada jalur antrian, sehingga tidak tahu lagi mana pasien yang datang duluan. Hal ini kadang-kadang menimbulkan perselisihan diantara pasien dan keluarga karena ada pasien yang sudah datang sejak subuh namun mendapatkan nomor antrian lebih belakang dibandingkan dengan pasien yang baru datang. Kejadian seperti ini hanya terjadi saat loket pengambilan nomor antrian baru dibuka karena dari awal sudah terjadi penumpukan pasien sekitar 50-60 orang, namun sesudah itu pengambilan nomor antrian sudah berjalan dengan tertib.

Berdasarkan teori, terdapat 4 jenis disiplin antrian, antara lain: ${ }^{12}$

1. First Come First Served (FCFS) atau First In First Out (FIFO) artinya, lebih 
dulu datang (sampai), lebih dulu dilayani (keluar). Misalnya, antrian pada loket pembelian tiket bioskop.

2. Last Come First Served (LCFS) atau Last In First Out (LIFO) artinya, yang tiba terakhir yang lebih dulu keluar. Misalnya, sistem antrian dalam elevator untuk lantai yang sama.

3. Service In Random Order (SIRO) artinya, panggilan didasarkan pada peluang secara random, tidak soal siapa yang lebih dulu tiba.

4. Priority Service (PS) artinya, prioritas pelayanan diberikan kepada pelanggan yang mempunyai prioritas lebih tinggi dibandingkan dengan pelanggan yang mempunyai prioritas lebih rendah, meskipun yang terakhir ini kemungkinan sudah lebih dahulu tiba dalam garis tunggu. Kejadian seperti ini kemungkinan disebabkan oleh beberapa hal, misalnya seseorang yang dalam keadaan penyakit lebih berat dibanding dengan orang lain dalam suatu tempat praktek dokter.

Di BKMM disiplin antrian untuk pengambilan nomor antrian belum dilaksanakan. Berdasarkan hasil wawancara dan observasi langsung di lapangan di dapatkan bahwa disiplin antrian ini belum dilaksanakan karena belum dibuat jalur antrian pasien hal ini karena adanya keterbatasan ruangan, dimana ruangan untuk pengambilan nomer antrian juga merupakan ruangan tunggu pasien.

\section{Waktu Proses/ Waktu Pelayanan}

Di BKMM Provinsi Sulut, terdapat 2 kategori pasien yaitu pasien lama dan pasien baru. Pasien lama atau pasien baru ini juga terbagi dua yaitu pasien BPJS dan pasien umum. Proses penerimaanpun berbeda antara pasien lama dan baru.

Untuk pasien baru umum maupun BPJS, saat dipanggil ke loket pendaftaran pasien diminta untuk mengisi formulir identitas pasien yang nantinya akan dicatat oleh petugas loket untuk dibuatkan kartu pengenal pasien dan kartu ini yang harus dibawa setiap kali akan datang berobat lagi di BKMM. Untuk pasien umum langsung dipersilahkan menungggu untuk mendapatkan pemeriksaan awal sementara petugas membuat berkas rekam mediknya. Untuk pasien BPJS harus melengkapi berkas yang menjadi persyaratan baru bisa dilayani. Apabila berkas tidak lengkap maka pasien harus melengkapi dulu dan kalau sudah lengkap pasien dipersilakan menunggu untuk mendapatkan pemeriksaan awal sementara petugas membuat SEP dan berkas rekam mediknya untuk kemudian diantar ke ruang pemeriksaan awal.

Untuk pasien lama, saat dipanggil ke loket pendaftran harus menunjukan kartu pengenal pasien (umum/ BPJS) dan berkas yang menjadi persyaratan (BPJS). Bila semuanya lengkap, pasien dipersilahkan menunggu sambil petugas membuat SEP (BPJS) dan mencari berkas rekam mediknya untuk diantar ke ruang pemeriksaan awal.

Berdasarkan wawancara mendalam lama waktu tunggu pasien mengenai waktu pelayanan diketahui bahwa pelaksanaan pelayanan pasien rawat jalan dimulai saat pasien dipanggil ke loket pendaftaran sesuai dengan nomor antriannya. Adapun kendala yang terjadi selama proses ini antara lain saat pasien dipanggil ke loket pendaftaran dan pasien adalah peserta BPJS, seringkali berkas-berkas yang dibawa tidak lengkap (tidak di fotokopi, di fotokopi tapi jumlahnya kurang) sehingga mereka harus pergi ke tempat fotokopi dulu baru kemudian kembali ke loket pendaftaran untuk dilayani, pasien tidak membawa kartu pengenal pasien (pasien lama), atau ada juga pasien yang membawa surat rujukan yang sudah tidak berlaku lagi. Selain itu jumlah petugas di loket pendaftaran masih kurang, petugas BPJS juga kurang, terjadi hambatan dalam pembuatan SEP karena terjadi gangguan koneksi internet, terjadi kesalahan penyimpanan berkas rekam medik pasien 
(human error), adanya petugas yang kurang tepat waktu dalam melaksanakan tugas serta pelayanan dokter belum per sub unit sehingga dalam pelayanan semua pasien harus melewati ruangan yang sama (keterbatasan ruangan).

Berdasarkan hasil observasi langsung dilapangan juga ditemukan hal-hal seperti yang sudah diutarakan oleh informaninforman. Selain itu didapati pendistribusian SEP dari ruang BPJS ke rekam medik menunggu berkas terkumpul dulu begitu juga dengan pendistribusian berkas rekam medik ke ruang pemeriksaan awal (minimal 5-10 berkas). Hal ini terjadi karena kurangnya petugas dan keterbatasan ruangan yang ada sehingga ruang rekam medik harus diletakkan di lantai 2 sehingga hal inilah yang meyebabkan berkas dikumpul dulu baru kemudian didistribusikan karena tidak mungkin petugas harus naik turun untuk membawa berkas satu persatu. Semua hal yang disebut diatas menyebabkan lama waktu tunggu pelayanan menjadi lama.

Dalam penelitian Andriyani ${ }^{11}$ mengenai sistem informasi pendaftaran pasien rawat jalan di RS dengan menggunakan program komputer juga didapatkan bahwa masalah yang sering muncul di instalasi rawat jalan adalah lamanya waktu tunggu penyampaian data rekam medik paien ke meja dokter, sehingga diperlukan sistem informasi manajeman RS yang bagus untuk mempercepat proses pencarian data pasien.

Hal yang hampir sama juga di sampaikan oleh Sulistiyorini ${ }^{12}$ dalam tinjauan faktor penyebab waktu tunggu pelayanan pendaftaran pasien umum rawat jalan di Rumah Sakit Umum Daerah (RSUD) Sragen dimana faktor yang yang memengaruhi lama tidaknya waktu tunggu pasien karena pasien lama tidak membawa KIB yang dapat mempengaruhi pencarian dokumen rekam medik, dokumen rekam medik yang tidak ditemukan dalam rak filing sehingga berpengaruh pada lama waktu tunggu pasien berikutnya.
Hal senada juga disampaikan oleh Febriyanti ${ }^{13}$ dalam deskripsi faktor-faktor yang memengaruhi waktu tunggu pendaftaran di TPPRJ RSUD Tugurejo Semarang tahun 2013, dimana didapatkan 10 faktor yang memengaruhi waktu tunggu, yaitu: pasien tidak membawa KIB, persyaratan pasien tidak lengkap, pasien lama mengaku sebagai pasien baru, SIM dan printer error, kurangnya komunikasi antara pasien dengan petugas sehingga pasien tidak membawa persyaratan pendaftaran dengan lengkap, pasien salah loket pendaftaran, dan pasien baru tidak mengisi form pendaftaran untuk pasien baru.

\section{Ketersediaan Sumber Daya (Manusia dan Material)}

Dari wawancara mendalam tentang lama waktu tunggu pelayanan mengenai SDM, dikatakan bahwa SDM sangat memengaruhi dalam melakukan pelayanan. Sebagian besar informan mengatakan secara umum jumlah SDM sudah cukup, hanya saja ada bagianbagian tertentu seperti loket pendaftaran (3-5 orang) dan petugas BPJS (2-3 orang) masih kurang dibandingkan jumlah kunjungan pasien per hari sebanyak 150-200 orang.

Berdasarkan pendidikan, BKMM hanya memiliki satu orang tenaga refraksionis, sehingga dalam melaksanakan pemeriksaan refraksi dibantu oleh beberapa perawat yang sudah dilatih di RSCM ataupun di RS Mata Cicendo. Hal ini bisa saja memengaruhi kecepatan pemeriksaan dan ketepatan pelayanan pasien. Saat ini di BKMM belum memiliki tenaga dengan latar belakang pendidikan perekam medis. Padahal dalam rekam medik banyak sekali hal yang harus dilakukan mulai dari penerimaan pasien, pencatatan, penyimpanan dan pengambilan kembali. Dalam pelayanan di BKMM tidak jarang berkas rekam medik pasien tercecer atau bahkan tidak ditemukan karena adanya kesalah dalam penyimpanan berkas rekam medik. Dalam penyelenggaraan pelayanan rawat jalan, semakin sedikit waktu yang 
terpakai untuk menyediakan dokumen rekam medis, maka waktu tuggu pelayanan akan semakin pendek. ${ }^{14}$

Masa kerja secara tidak langsung ikut memengaruhi waktu pelayanan pasien. Masa kerja berhubungan dengan pengalaman. Pengalaman merupakan suatu cara untuk memperoleh kebenaran pengetahunan dalam upaya meningkatkan pelayanan kepada pasien.

\section{SIMPULAN}

Berdasarkan wawancara dan observasi yang dilakukan di BKMM Provinsi Sulut dapat disimpulkan bahwa waktu tunggu di BKMM Provinisi Sulut masih tergolong lama (> 60 menit). Hal ini disebabkan jumlah pasien yang banyak, kurangnya petugas di loket pendaftaran dan BPJS, gangguan koneksi internet, pendistribusian berkas rekam medik yang sering terlambat, keterbatasan ruangan yang ada, dan keterbatasan SDM yang mempunyai keahlian di bidang refraksi dan rekam medik

\section{DAFTAR PUSTAKA}

1. Anonim. Definisi, Tugas dan Fungsi Rumah Sakit menurut WHO. http://kedaiobat.co.cc.wordpress.com/2 010/05124/definisi-tugas-dan-fungsirumah-sakit-menurut-who/. 2010

2. Anonim. Undang-undang Republik Indonesia Nomor 44 tahun 2009 tentang Rumah Sakit. 2009.

3. Arieta R. Analisis Waktu Tunggu Pasien di Departeman Gigi dan Mulut RSPAD Gatot Soebroto Ditkesad Tahun 2011. Fakultas Kesehatan Masyarakat [Tesis]. Jakarta: Program Studi Kajian Administrasi Rumah Sakit Universitas Indonesia; 2012.

4. Esti A. Pengaruh Waktu Tunggu dan Waktu Sentuh Pasien terhadap Tingkat Kepuasan Pasien Poli Umum di Puskesmas Sukorame Kota Kediri. Publikasi.stikesstrada.ac.id/wpcontent/uploads/2015/02/8-
PENGARUH WAKTU TUNGGU.pdf. 2012.

5. Anonim. Keputusan Menteri Kesehatan Republik Indonesia Nomor 129 tentang Standar Pelayanan Minimal Rumah Sakit. Kemenkes RI. Jakarta. 2008

6. Anonim. Profil Balai Kesehatan Mata Masyarakat Provinsi Sulawesi Utara. 2014.

7. Putra N. Penelitian Kualitatif: Proses dan Aplikasi Indeks. Jakarta: Indeks, 2011.

8. Utomo $\mathbf{N}$, Wibowo NC, Wahjudijanto $\mathbf{I}$. Aplikasi sistem informasi pada pelayanan penumpang di fasilitas check in counter terminal domestic Bandar udara Juanda Surabaya [Project report]. Surabaya: UPN Veteran Jatim, 2013.

9. Khasanah, Uswatun H. Simulasi Sistem Pelayanan Pasien pada Poli Mata di RSU Kabupaten Gresik. digilib.its.ac.id/ITS-Undergraduate3100004020910/10294. 2010.

10.Aditama T. Distribusi Waktu Tunggu pada Antrian dengan Menggunakan Disiplin Pelayanan Prioritas (Studi Kasus: Instalasi Rawat Darurat di RSUD Dr. Soetomo Surabaya). Jurnal Sains dan Seni Pomits 2013;1(1):1-6.

11.Andriyani L. Sistem informasi pendaftaran pasien rawat jalan di Rumah Sakit dengan menggunakan program komputer [Skripsi]. Bandung: Universitas Komputer Indonesia; 2009.

12. Sulistiyorini C, Lestari T, Rohmadi. Tinjauan faktor penyebab waktu tunggu pelayanan pendaftaran pasien umum rawat jalan di RSUD Sragen. Rekam Medis. 2012;6(2).

13. Febrianti DH, Kurniadi A. Deskripsi faktor-faktor yang memengaruhi waktu tunggu pendaftaran di TPPRJ RSUD Tugurejo Semarang tahun 2013. eprints.dinus.ac.id/7822/1/jurnal_12667 .pdf. 2013.

14.Anonim. Peraturan Menteri Kesehatan Republik Inonesia Nomor 269 tentang Rekam Medis. Kemenkes RI. Jakarta. $2008_{b}$. 